\title{
Classification schemes for knowledge translation interventions: a practical resource for researchers
}

Susan E. Slaughter ${ }^{1 *}$, Gabrielle L. Zimmermann ${ }^{2,3}$, Megan Nuspl ${ }^{2}$, Heather M. Hanson ${ }^{3,4}$, Lauren Albrecht ${ }^{1}$, Rosmin Esmail ${ }^{3,4}$, Khara Sauro $^{4}$, Amanda S. Newton ${ }^{1}$, Maoliosa Donald ${ }^{3}$, Michele P. Dyson ${ }^{1}$, Denise Thomson ${ }^{2}$ and Lisa Hartling ${ }^{1,2}$

\begin{abstract}
Background: As implementation science advances, the number of interventions to promote the translation of evidence into healthcare, health systems, or health policy is growing. Accordingly, classification schemes for these knowledge translation (KT) interventions have emerged. A recent scoping review identified 51 classification schemes of KT interventions to integrate evidence into healthcare practice; however, the review did not evaluate the quality of the classification schemes or provide detailed information to assist researchers in selecting a scheme for their context and purpose. This study aimed to further examine and assess the quality of these classification schemes of KT interventions, and provide information to aid researchers when selecting a classification scheme.
\end{abstract}

Methods: We abstracted the following information from each of the original 51 classification scheme articles: authors' objectives; purpose of the scheme and field of application; socioecologic level (individual, organizational, community, system); adaptability (broad versus specific); target group (patients, providers, policy-makers), intent (policy, education, practice), and purpose (dissemination versus implementation). Two reviewers independently evaluated the methodological quality of the development of each classification scheme using an adapted version of the AGREE II tool. Based on these assessments, two independent reviewers reached consensus about whether to recommend each scheme for researcher use, or not.

Results: Of the 51 original classification schemes, we excluded seven that were not specific classification schemes, not accessible or duplicates. Of the remaining 44 classification schemes, nine were not recommended. Of the 35 recommended classification schemes, ten focused on behaviour change and six focused on population health. Many schemes $(n=29)$ addressed practice considerations. Fewer schemes addressed educational or policy objectives. Twenty-five classification schemes had broad applicability, six were specific, and four had elements of both. Twenty-three schemes targeted health providers, nine targeted both patients and providers and one targeted policy-makers. Most classification schemes were intended for implementation rather than dissemination.

Conclusions: Thirty-five classification schemes of KT interventions were developed and reported with sufficient rigour to be recommended for use by researchers interested in $\mathrm{KT}$ in healthcare. Our additional categorization and quality analysis will aid in selecting suitable classification schemes for research initiatives in the field of implementation science.

Keywords: Knowledge translation interventions, Classification schemes, AGREE II tool, Healthcare, Implementation science

* Correspondence: sslaught@ualberta.ca

${ }^{1}$ University of Alberta, Edmonton, Canada

Full list of author information is available at the end of the article

(c) The Author(s). 2017 Open Access This article is distributed under the terms of the Creative Commons Attribution 4.0 International License (http://creativecommons.org/licenses/by/4.0/), which permits unrestricted use, distribution, and reproduction in any medium, provided you give appropriate credit to the original author(s) and the source, provide a link to the Creative Commons license, and indicate if changes were made. The Creative Commons Public Domain Dedication waiver (http://creativecommons.org/publicdomain/zero/1.0/) applies to the data made available in this article, unless otherwise stated. 


\section{Background}

With the advancement of implementation science, knowledge translation (KT) interventions to promote the translation of research evidence into practice are increasing considerably. KT interventions can target different levels such as health providers (e.g., reminders to complete a new health assessment), health systems (e.g., introduction of a new form to facilitate documentation) and health policy (e.g., reimbursement scheme to encourage a new practice). With the growth in KT interventions, taxonomies or classifications schemes have begun to emerge to help clarify details, promote consistency in reporting, and facilitate an understanding of the interventions.

A recent scoping review by Lokker et al. identified 51 diverse classification schemes of interventions to promote and integrate evidence into healthcare practice [1]. The review provides researchers with a high level overview of schemes to classify $\mathrm{KT}$ interventions with the intent to address challenges of detailed describing and reporting of interventions. One important limitation to this review is the paucity of information to guide researchers in selecting a particular scheme suitable for their context and purpose. Guidance exists for selecting models, theories, and frameworks to assist with interpretation of study findings and to ensure the inclusion of essential implementation strategies [2, 3]. For example, one recent narrative review identified 41 different conceptual frameworks to describe and measure key elements of the process for translating research evidence into policy and practice [4]. Another narrative review identified 61 theories and models to provide a systematic way of understanding, developing and evaluating dissemination and implementation research [2]. Furthermore, an interactive website exists to help researchers and practitioners select the dissemination and implementation model that best fits their research question or practice problem [3]. While this guidance can help direct development, selection or evaluation of KT interventions [2-4], it does not provide guidance for consistent description of $\mathrm{KT}$ interventions. Both are important to improve the reporting and generalizability of KT interventions.

Lokker et al. acknowledged that additional work is needed to be able to apply these classification schemes in an optimal and meaningful way by researchers [1]. Furthermore, critical appraisal or quality assessment of the classification schemes would provide important information on the rigour of the schemes' development. To address these gaps, the Knowledge Translation Methods Working Group, which is an initiative of the Knowledge Translation Platform of the Alberta Strategy for Patient Oriented Research (SPOR) SUPPORT Unit, undertook a more in-depth analysis of the classification schemes identified by Lokker et al. The purpose of this study was to examine the classification schemes in more detail, extract additional information, and assess the developmental and methodological quality of each, in order to guide researchers to the tool that might be most appropriate for their specific purpose and context.

\section{Methods \\ General approach}

The Alberta SPOR SUPPORT Unit's Knowledge Translation Platform established a working group involving platform staff, as well as academics, trainees, and health service employees across the province with an interest in KT science. Through discussion and consensus, the working group identified an in-depth analysis of the classification schemes for the implementation of evidence into healthcare as a priority area within KT. The group met biweekly (on average) over the course of a year, and collectively developed the project scope and methods, collected and analyzed data, discussed findings, developed consensus and drafted the final report.

\section{Description of classification schemes Data collection}

The original paper [1] provided very general information about each scheme including: sorting schemes as lists, taxonomies, frameworks, or 'other'; reporting context, focus and brief methodological notes; and indicating if the scheme had been peer reviewed, involved knowledge users in its development, was piloted or tested, or was theory based. The working group members independently extracted the following additional information: authors' objectives; purpose of the classification scheme; field of application (e.g., public health, tobacco control, mental health); adaptability (i.e., broad versus specific); whether the interventions targeted patients, providers, or policy makers; socioecologic level; dissemination versus implementation; and focus of implementation, referred to as intent. Through consensus, the working group identified these additional data as useful in the selection of a classification scheme for use in KT research.

Adaptability of schemes, socioecologic level, and dissemination versus implementation were adapted from a previous review of models for dissemination and implementation research [2]. Adaptability of schemes was categorized as broad versus specific, relative to the application and/or operationalization of the classification scheme [2]. Socioecologic level, defined as level of influence, was categorized as individual, organization, community, and system [2]. In addition to these structural levels of influence, we sought to identify which specific target group the interventions within the classification schemes applied to (i.e. patients, providers or policy makers). Focus of implementation, or intent, was categorized as clinical practice, education, or policy. Socioecologic level and intent categories were not mutually 
exclusive (i.e., a given classification scheme could have more than one). As per the definitions provided by Tabak et al., dissemination is "focus on active approach of spreading evidence-based interventions to the target audience via determined channels using planned strategies" whereas implementation is "focus on process of putting to use or integrating evidence-based interventions within a setting" [2]. We also abstracted information on methodology, including whether the scheme was peer-reviewed, involved knowledge users in its development, was piloted or tested, and was theory based, in order to provide a comprehensive description of each [1]. Extracted data were independently assessed by a second reviewer during quality appraisal. Both reviewers also independently assessed the utility of each classification scheme.

In order to gain an understanding of the use of each classification scheme, each article was searched in Scopus by title. The total number of citations in the past five years, the subject area of the citations (as defined by Scopus, e.g., medicine, psychology, nursing), and the document type (e.g., articles, reviews, conference papers) were recorded.

\section{Quality appraisal}

In the absence of an established tool to appraise the methodological quality of the classification schemes, we used the AGREE II tool as the basis for developing our appraisal tool. The AGREE II tool is well recognized, has been rigorously developed and covers many aspects of quality relevant to classification schemes [5]. The AGREE II tool was designed to be applied to clinical practice guidelines; therefore, we adapted the tool to make the items relevant to KT classification schemes. All working group members were involved in making the adaptations based on an iterative process of applying the tool to a sample of articles, and discussing challenges and appropriateness of the items. In this way, the working group, made up of relevant knowledge users, was able to provide face validity and initial content validity for the adapted tool to assess quality of KT classification schemes. The adapted AGREE II tool includes six domains that are each scored on a seven-point Likert scale (strongly disagree $=1$ to strongly agree $=7$ ). The overall score, in both the original and our adapted version, is not based on a mathematical computation of the domain scores. Instead, the score, which ranges from 1 (lowest possible quality) to 7 (highest possible quality), is based on overall impressions of the classification scheme, which take the six domains into account. An additional file shows the adapted domains of the AGREE II tool [see Additional file 1]. The 12 members of the working group were randomly assigned to conduct a quality appraisal of the articles such that two people independently assessed each article and the pair arrived at consensus for each domain and overall rating. In this way each member worked with several others; this helped identify questions or areas of discrepancy which were brought to the full working group for discussion, then decision rules were established to ensure consistency. These decision rules were sufficient to eliminate any further major discrepancies in ratings (and allowed the reviewers to come to within 2 points and/or achieve consensus easily?). In accordance with AGREE II guidance, classification schemes were recommended for use, or not recommended for use by the pair of working group members reviewing the classification scheme, based on the quality score, in conjunction with their overall impression of the classification schemes' utility. All classification schemes that were not recommended were discussed with the full working group. Members of the working group, comprising researchers from academia and health services, who are potential knowledge users of these classification schemes, were able to assess the utility of the classification schemes for intended users.

\section{Data analysis}

We summarize our findings using descriptive statistics. To understand the context around previous use of the classification schemes, independent sample t-tests were used to compare the years of publication and number of Scopus citations per year since publication of the recommended and not recommended classification schemes.

\section{Results}

\section{Recommended classification schemes}

Figure 1 illustrates the flow of the articles within our study. During our initial data extraction, we excluded seven articles that had originally been included by Lokker et al. [1]. One was a website that was no longer active [6]; two were textbooks that provided general information but not a specific classification scheme [7, 8]; three did not describe a specific KT classification scheme [9-11]; and one was considered a duplicate [12].

After excluding articles that were not accessible, duplicates, or not focused on a specific KT classification scheme, we included 44 articles in our descriptive analysis and quality appraisal. Nine articles [13-21] were assessed to be of low quality, or did not provide schemes that were deemed useful for KT researchers as judged by our working group of knowledge users. Table 1 summarizes details of the articles containing classification schemes that were not recommended.

Thirty-five articles [22-56] were recommended. A description of the recommended classification schemes can be found in Table 2 . In most cases the quality appraisals aligned with the recommendations; however there were four exceptions. Two low-scoring classification schemes 


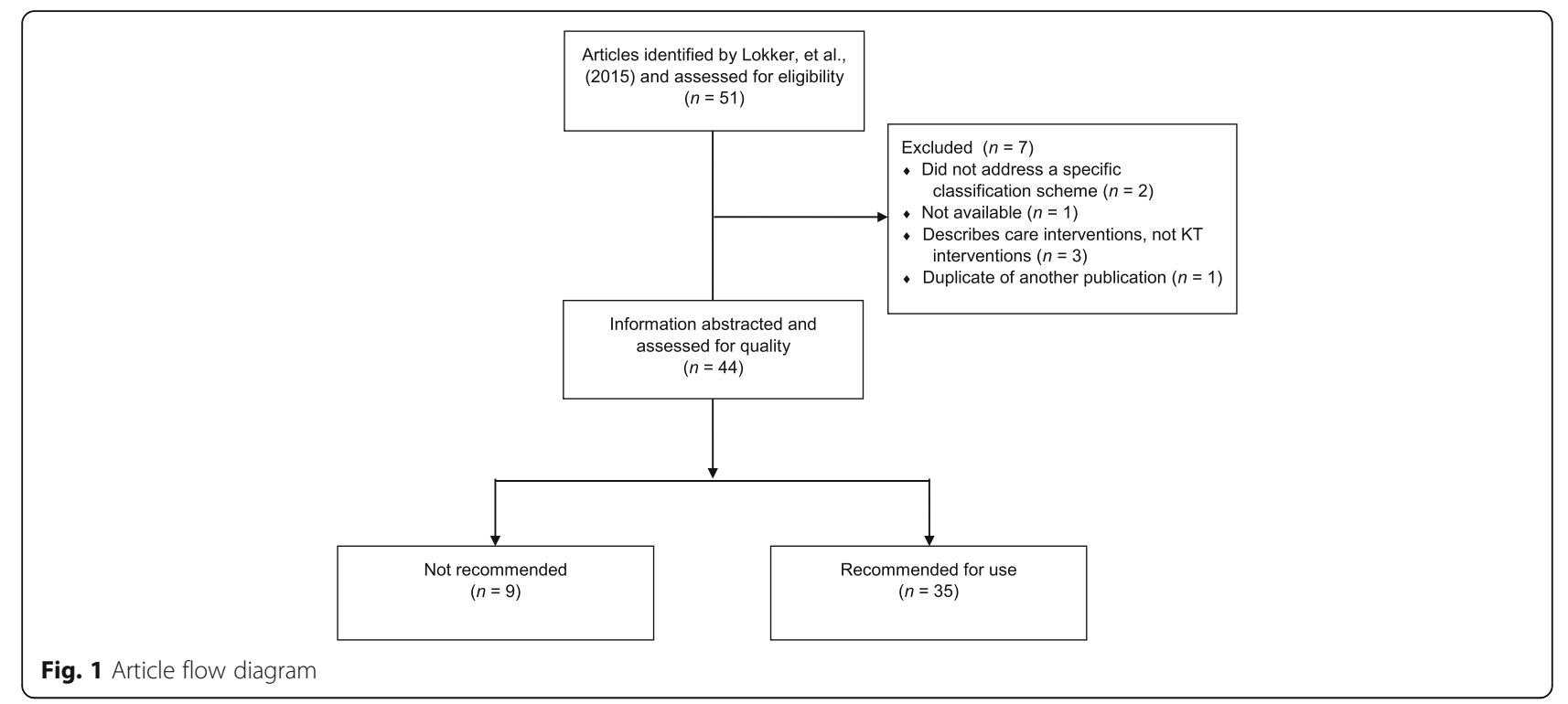

were recommended [26, 49], and two intermediatescoring classification schemes were not recommended $[14,15]$. The low-scoring classification schemes were assigned a two and a three because little to no information was provided about how the classification schemes were developed. These two schemes classified interventions to implement evidence into healthcare involving reimbursement schemes [26] and public health policy initiatives, [49] respectively. We opted to recommend them because, in the absence of any other classification schemes for these areas of healthcare, they offer unique and potentially useful contributions to the KT literature. Conversely, the classification schemes reported by Embry et al. [15] and Dolan et al. [14] both scored a four; however we did not recommend these classification schemes. The paper by Embry et al. [15] did not focus

Table 1 Classification schemes of KT interventions that were not recommended for use

\begin{tabular}{|c|c|c|c|c|c|}
\hline Article & Purpose of Classification Scheme & $\begin{array}{l}\text { Area of } \\
\text { Application }\end{array}$ & Citations $^{a}$ & Quality Score ${ }^{b}$ & Rationale for Not Recommending \\
\hline $\begin{array}{l}\text { Cohen } 2000 \\
\text { [13] }\end{array}$ & $\begin{array}{l}\text { To outline and clarify the content } \\
\text { of preventative interventions }\end{array}$ & $\begin{array}{l}\text { STD/HIV } \\
\text { prevention }\end{array}$ & 27 & 3 & $\begin{array}{l}\text { Low scores across all domains, modification of } \\
\text { existing tool with minimal detail on development }\end{array}$ \\
\hline $\begin{array}{l}\text { Dolan } 2010 \\
\text { [14] }\end{array}$ & To shape policy maker behaviour & Policy & 254 & 4 & $\begin{array}{l}\text { Poor rigour of development; does not seem useful } \\
\text { for researchers }\end{array}$ \\
\hline $\begin{array}{l}\text { Embry } 2008 \\
{[15]}\end{array}$ & $\begin{array}{l}\text { To provide a database repository } \\
\text { of evidence-based units of } \\
\text { behavioural influence }\end{array}$ & $\begin{array}{l}\text { Parenting, school, } \\
\text { \& public health } \\
\text { behaviour }\end{array}$ & 88 & 4 & $\begin{array}{l}\text { Poor rigour of development and applicability, not } \\
\text { intended as a development document, creates a } \\
\text { care-focused sample }\end{array}$ \\
\hline $\begin{array}{l}\text { Geller } 1990 \\
\text { [16] }\end{array}$ & $\begin{array}{l}\text { To outline a conceptual framework } \\
\text { for traffic safety, especially use of } \\
\text { seat belts }\end{array}$ & Injury prevention & 51 & 3 & $\begin{array}{l}\text { Complex and outdated; poor rigour of } \\
\text { development, applicability and KU involvement }\end{array}$ \\
\hline $\begin{array}{l}\text { Goel } 1996 \\
{[17]}\end{array}$ & $\begin{array}{l}\text { To outline influences on retail } \\
\text { pharmacies in developing } \\
\text { countries }\end{array}$ & $\begin{array}{l}\text { Pharmacy } \\
\text { behaviours }\end{array}$ & 114 & 3 & $\begin{array}{l}\text { Low scores in rigour of development, applicability, } \\
\text { and editorial independence }\end{array}$ \\
\hline $\begin{array}{l}\text { Hardeman } \\
2000[18]\end{array}$ & $\begin{array}{l}\text { To describe behaviour change } \\
\text { programmes }\end{array}$ & $\begin{array}{l}\text { Population/ public } \\
\text { health }\end{array}$ & 178 & 2 & $\begin{array}{l}\text { Low scores for scope and purpose, stakeholder/KU } \\
\text { involvement, aspects of rigour, and applicability }\end{array}$ \\
\hline $\begin{array}{l}\text { Perdue } 2005 \\
{[19]}\end{array}$ & $\begin{array}{l}\text { To describe different legal } \\
\text { strategies for chronic disease } \\
\text { prevention }\end{array}$ & $\begin{array}{l}\text { Policy \& public } \\
\text { health }\end{array}$ & 17 & 3 & $\begin{array}{l}\text { Low scores in areas of rigour of development and } \\
\text { applicability }\end{array}$ \\
\hline $\begin{array}{l}\text { Reisman } \\
2005[20]\end{array}$ & $\begin{array}{l}\text { To provide a taxonomy for transfer } \\
\text { of technology }\end{array}$ & $\begin{array}{l}\text { Technology } \\
\text { transfer }\end{array}$ & 36 & 3 & $\begin{array}{l}\text { Low scores in rigour of development, applicability, } \\
\text { and editorial independence }\end{array}$ \\
\hline $\begin{array}{l}\text { West } 2006 \\
{[21]}\end{array}$ & $\begin{array}{l}\text { To review tobacco control } \\
\text { strategies }\end{array}$ & Behaviour change & 28 & 2 & $\begin{array}{l}\text { Low scores for scope and purpose, stakeholder/KU } \\
\text { involvement, aspects of rigour, and applicability }\end{array}$ \\
\hline
\end{tabular}

${ }^{a}$ Number of citations for each article via title search in Scopus

${ }^{\mathrm{b}}$ Quality score is the overall adapted AGREE II score, reached by consensus between two researchers 
Table 2 Classification schemes of KT interventions that were recommended for use

\begin{tabular}{|c|c|c|c|c|c|}
\hline Article & Purpose of Classification Scheme & $\begin{array}{l}\text { Area of } \\
\text { Application }\end{array}$ & Context of Previous Use ${ }^{a}$ & $\begin{array}{l}\text { Number } \\
\text { of } \\
\text { Citations }^{\text {b }}\end{array}$ & $\begin{array}{l}\text { Quality } \\
\text { Score }^{c}\end{array}$ \\
\hline $\begin{array}{l}\text { Abraham } \\
2008[22]\end{array}$ & $\begin{array}{l}\text { To provide a common vocabulary for behaviour change } \\
\text { interventions }\end{array}$ & $\begin{array}{l}\text { Behaviour } \\
\text { change }\end{array}$ & $\begin{array}{l}\text { Physical activity, healthy } \\
\text { eating, change in cognition, } \\
\text { HIV/AIDS }\end{array}$ & 816 & 6 \\
\hline $\begin{array}{l}\text { Albrecht } 2013 \\
\text { [23] }\end{array}$ & $\begin{array}{l}\text { To compare quality of reporting and types of } \mathrm{KT} \text { interventions } \\
\text { being used }\end{array}$ & $\begin{array}{l}\text { Behaviour } \\
\text { change }\end{array}$ & - & 44 & 5 \\
\hline Best 2008 [24] & To improve past Cancer Control Frameworks & $\begin{array}{l}\text { Cancer practice } \\
\& \text { policy }\end{array}$ & Cancer practice \& policy & 54 & 4 \\
\hline $\begin{array}{l}\text { Cane } 2012 \\
{[25]}\end{array}$ & $\begin{array}{l}\text { To "simplify and integrate" multiple behaviour change theories, } \\
\text { by refining the theoretical domains framework (TDF) }\end{array}$ & $\begin{array}{l}\text { Behaviour } \\
\text { change }\end{array}$ & - & 259 & 6 \\
\hline $\begin{array}{l}\text { Carlson } 2010 \\
{[26]}\end{array}$ & $\begin{array}{l}\text { To categorize future health outcomes-based reimbursement } \\
\text { schemes }\end{array}$ & $\begin{array}{l}\text { Reimbursement } \\
\text { schemes }\end{array}$ & - & 107 & 2 \\
\hline $\begin{array}{l}\text { Century } 2012 \\
{[27]}\end{array}$ & $\begin{array}{l}\text { To understand (1) aspects of implementation, (2) factors that } \\
\text { affect implementation, and (3) tools for measuring these }\end{array}$ & Education & - & 9 & 5 \\
\hline $\mathrm{CIHI} 2001[28]$ & $\begin{array}{l}\text { To summarize strategies by target audience, timing and } \\
\text { methods }\end{array}$ & $\begin{array}{l}\text { Population } \\
\text { health }\end{array}$ & $\begin{array}{l}\text { Health policy \& decision } \\
\text { making }\end{array}$ & $\begin{array}{l}\text { Not } \\
\text { found }\end{array}$ & 4 \\
\hline $\begin{array}{l}\text { Czaja } 2003 \\
{[29]}\end{array}$ & Taxonomy of complex psychosocial and behaviour interventions & $\begin{array}{l}\text { Alzheimer's } \\
\text { disease }\end{array}$ & Alzheimer's disease & 42 & 5 \\
\hline $\begin{array}{l}\text { Damschroder } \\
2009[30]\end{array}$ & $\begin{array}{l}\text { List of constructs to promote theory development and } \\
\text { verification across multiple settings }\end{array}$ & Multiple & - & 1101 & 6 \\
\hline $\begin{array}{l}\text { Dixon } 2010 \\
{[31]}\end{array}$ & $\begin{array}{l}\text { To describe competency domains for health behaviour change } \\
\text { interventions }\end{array}$ & $\begin{array}{l}\text { Behaviour } \\
\text { change }\end{array}$ & Public health & 8 & 6 \\
\hline $\begin{array}{l}\text { Dogherty } \\
2010[32]\end{array}$ & $\begin{array}{l}\text { Taxonomy of facilitation interventions/strategies and facilitator } \\
\text { role synopsis }\end{array}$ & $\begin{array}{l}\text { Nursing } \\
\text { implementation }\end{array}$ & Nursing & 50 & 4 \\
\hline Dy 2011 [33] & To classify patient safety practices & Patient safety & Patient safety & 12 & 6 \\
\hline $\begin{array}{l}\text { EPOC } 2010 \\
{[34]}\end{array}$ & $\begin{array}{l}\text { To (1) help authors register a title with EPOC; and (2) address } \\
\text { key issues that frequently arise in EPOC protocols and reviews in } \\
\text { the background and methods section }\end{array}$ & Health care & - & $\begin{array}{l}\text { Not } \\
\text { found }\end{array}$ & 6 \\
\hline $\begin{array}{l}\text { Galbraith } \\
2011[35]\end{array}$ & $\begin{array}{l}\text { To identify elements of behavioural interventions that guide } \\
\text { translation of interventions from research to practice }\end{array}$ & $\begin{array}{l}\text { HIV/AIDS } \\
\text { prevention }\end{array}$ & HIV/AIDS Prevention & 20 & 6 \\
\hline $\begin{array}{l}\text { Gifford } 2013 \\
{[36]}\end{array}$ & To inform future research about leadership behaviour & Nursing & Nursing & 18 & 6 \\
\hline $\begin{array}{l}\text { Greenhalgh } \\
2004[37]\end{array}$ & $\begin{array}{l}\text { To use for diffusion of innovations in health services } \\
\text { organizations }\end{array}$ & Health services & - & 2207 & 5 \\
\hline $\begin{array}{l}\text { Hendriks } 2013 \\
{[38]}\end{array}$ & $\begin{array}{l}\text { To facilitate action-oriented approach for policy makers } \\
\text { addressing wicked problems }\end{array}$ & $\begin{array}{l}\text { Population } \\
\text { health }\end{array}$ & $\begin{array}{l}\text { Population health \& health } \\
\text { policy }\end{array}$ & 16 & 5 \\
\hline $\begin{array}{l}\text { Keller } 2004 \\
{[39]}\end{array}$ & To identify and document interventions for public health nurses & Public health & Public health nursing & 68 & 6 \\
\hline $\begin{array}{l}\text { Lamb } 2011 \\
{[40]}\end{array}$ & Taxonomy of interventions used to prevent falls in older adults & $\begin{array}{l}\text { Geriatric } \\
\text { medicine }\end{array}$ & $\begin{array}{l}\text { Injury prevention \& geriatric } \\
\text { medicine }\end{array}$ & 34 & 5 \\
\hline $\begin{array}{l}\text { Lavis } 2006 \\
{[41]}\end{array}$ & To inform national level dialogue on linking research to action & $\begin{array}{l}\text { Knowledge } \\
\text { translation }\end{array}$ & - & 171 & 5 \\
\hline $\begin{array}{l}\text { Leeman } 2007 \\
\text { [42] }\end{array}$ & Taxonomy categorizing implementation methods & Nursing & - & 48 & 4 \\
\hline $\begin{array}{l}\text { Lowe } 2011 \\
\text { [43] }\end{array}$ & Taxonomy of interventions to improve consumers' medicines & $\begin{array}{l}\text { Patient safety; } \\
\text { behaviour } \\
\text { change }\end{array}$ & Prescribing practices & 9 & 6 \\
\hline $\begin{array}{l}\text { Mazza } 2013 \\
{[44]}\end{array}$ & $\begin{array}{l}\text { Taxonomy to classify the nature and content of implementation } \\
\text { strategies }\end{array}$ & $\begin{array}{l}\text { Implementation } \\
\text { science }\end{array}$ & - & 19 & 4 \\
\hline $\begin{array}{l}\text { Michie 2011a } \\
\text { [45] }\end{array}$ & To link interventions to potential behavioural targets & $\begin{array}{l}\text { Behaviour } \\
\text { change }\end{array}$ & Tobacco control \& obesity & 557 & 7 \\
\hline $\begin{array}{l}\text { Michie } 2011 \mathrm{~b} \\
{[46]}\end{array}$ & $\begin{array}{l}\text { To provide basis for improving reliable and systematic } \\
\text { application of evidence and theory for interventions }\end{array}$ & $\begin{array}{l}\text { Behaviour } \\
\text { change }\end{array}$ & $\begin{array}{l}\text { Physical activity \& healthy } \\
\text { eating }\end{array}$ & 345 & 6 \\
\hline $\begin{array}{l}\text { Michie 2011c } \\
\text { [47] }\end{array}$ & $\begin{array}{l}\text { Taxonomy of behaviour change techniques for smoking } \\
\text { cessation }\end{array}$ & Behaviour change & $\begin{array}{l}\text { Smoking cessation \& health } \\
\text { promotion }\end{array}$ & 114 & 6 \\
\hline
\end{tabular}


Table 2 Classification schemes of KT interventions that were recommended for use (Continued)

\begin{tabular}{|c|c|c|c|c|c|}
\hline Article & Purpose of Classification Scheme & $\begin{array}{l}\text { Area of } \\
\text { Application }\end{array}$ & Context of Previous Use ${ }^{a}$ & $\begin{array}{l}\text { Number } \\
\text { of } \\
\text { Citations }^{\text {b }}\end{array}$ & $\begin{array}{l}\text { Quality } \\
\text { Score }^{c}\end{array}$ \\
\hline $\begin{array}{l}\text { Michie } 2012 \\
{[48]}\end{array}$ & $\begin{array}{l}\text { To identify behaviour change techniques used to reduce } \\
\text { excessive alcohol consumption }\end{array}$ & $\begin{array}{l}\text { Behaviour } \\
\text { change }\end{array}$ & Reduction of alcohol consumption & 64 & 6 \\
\hline $\begin{array}{l}\text { Nuffield } 2007 \\
\text { [49] }\end{array}$ & To justify different policy initiatives in public health & Public health & $\begin{array}{l}\text { Infectious disease, obesity, smoking/ } \\
\text { alcohol \& water fluoridation }\end{array}$ & $\begin{array}{l}\text { Not } \\
\text { found }\end{array}$ & 3 \\
\hline $\begin{array}{l}\text { Powell } 2012 \\
{[50]}\end{array}$ & To provide implementation strategies for innovations & Mental health & Mental health & 117 & 6 \\
\hline $\begin{array}{l}\text { Schulz } 2010 \\
{[51]}\end{array}$ & $\begin{array}{l}\text { To assess the relationships between outcomes and intervention } \\
\text { components }\end{array}$ & $\begin{array}{l}\text { Implementation } \\
\text { science }\end{array}$ & Implementation science & 45 & 6 \\
\hline $\begin{array}{l}\text { Shojania } 2004 \\
\text { [52] }\end{array}$ & $\begin{array}{l}\text { To help users assess whether evidence suggests that a quality } \\
\text { improvement strategy is applicable to their context }\end{array}$ & $\begin{array}{l}\text { Quality } \\
\text { improvement }\end{array}$ & Multiple disease areas & $\begin{array}{l}\text { Not } \\
\text { found }\end{array}$ & 6 \\
\hline $\begin{array}{l}\text { Stirman } 2013 \\
\text { [53] }\end{array}$ & $\begin{array}{l}\text { To classify modifications to evidence-based programs during } \\
\text { implementation }\end{array}$ & $\begin{array}{l}\text { Implementation } \\
\text { science }\end{array}$ & - & 40 & 6 \\
\hline $\begin{array}{l}\text { Taylor } 2011 \\
{[54]}\end{array}$ & $\begin{array}{l}\text { To categorize contextual features influencing successful } \\
\text { implementation }\end{array}$ & Patient safety & - & 66 & 6 \\
\hline $\begin{array}{l}\text { Walter } 2003 \\
{[55]}\end{array}$ & To increase the impact of research & $\begin{array}{l}\text { Policy \& behaviour } \\
\text { change }\end{array}$ & - & 45 & 4 \\
\hline $\begin{array}{l}\text { Ward } 2010 \\
{[56]}\end{array}$ & $\begin{array}{l}\text { To improve success of incorporating research-based knowledge } \\
\text { into action }\end{array}$ & $\begin{array}{l}\text { Knowledge } \\
\text { translation }\end{array}$ & - & 71 & 6 \\
\hline
\end{tabular}

${ }^{a}$ Area where scheme has previously been tested. Those with - have not been tested in any specific context

${ }^{b}$ Number of citations for each article via title search in Scopus

'Quality score is the overall adapted AGREE II score, reached by consensus between two researchers

on a classification scheme for interventions to implement evidence into healthcare; rather it focused on behavioral prevention and treatment practices and only a partial classification scheme was presented [15]. Dolan et al. provided a checklist of influences on behaviour that should be considered in public policy making [14]; the checklist received low scores in rigour of development which reflected the assessment that it was not a useful classification scheme for KT researchers.

There was a significant difference in the year of publication for the classification schemes recommended and not recommended; recommended classification schemes were more recently published $($ Mean $=2009, S D=3.3$ ) than schemes not recommended (Mean $=2002, S D=6.3$; $p<0.05)$. We also found a significant difference in the number of citations normalized over the years since publication between the recommended (Mean $=24.8$, $S D=41.4)$ and not recommended (Mean $=8.0, S D=$ $11.1), p<0.05)$ classification schemes $(p<0.05)$.

\section{Field of application and adaptability of schemes}

We assessed the field of application for each recommended classification scheme. Ten schemes focused on behaviour change [22, 23, 29, 31, 43, 45-48, 55], six focused on population health $[28,38-41,49]$, and 19 schemes had general applicability [24-27, 30, 32-37, 42, 44, 50-54, 56]. Table 3 summarizes details for all recommended schemes.

We also categorized the intent of the intervention of the included schemes within the domains of practice, education, and/or policy. Many schemes $(n=29)$ addressed practice considerations [22-25, 29-37, 39-43, $45-48,50-56]$. Fewer schemes addressed educational ( $n$ =13) $[23,24,27,29-31,33-35,37,43,52,53]$ and policy $(n=20)$ objectives $[24,26,28,30,31,33,34,37,38$, $41,43-45,47-49,52,53,55,56]$.

The adaptability of each classification scheme was assessed as either broad (defined as greater flexibility to apply the scheme to a wide array of contexts/clinical areas) or specific (defined as the scheme being developed for a specific context/clinical area). The vast majority of schemes had broad adaptability $(n=25)[22,23$, 25-28, 30-32, 34, 35, 37-39, 41-44, 49, 50, 52-56]. In contrast, six schemes were identified as specific, offering detailed actions for dissemination and implementation $[33,36,40,46,47,51]$. The remaining four schemes included elements of both broad and specific adaptability $[24,29,45,48]$.

\section{Level of influence of schemes}

There was diversity in the socioecologic level or level of influence of the classification schemes. Seven of the 35 schemes targeted a single level while the remaining 28 schemes targeted two or more levels. The level least targeted within the schemes was the community level, such as neighbourhoods or local governments $(n=14)$ [23, $24,28-30,33-35,37,39,52,53,55,56]$. The individual level, organizational level, and system levels were roughly equally targeted, with 23-26 schemes addressing each of these levels. 
Table 3 Details of recommended classification schemes for KT interventions

\begin{tabular}{|c|c|c|c|c|c|c|c|c|c|c|}
\hline \multirow[t]{2}{*}{ Article } & \multirow{2}{*}{$\begin{array}{l}\text { Adaptability } \\
\text { of Schemes } \\
B=\text { Broad } \\
S=\text { Specific }\end{array}$} & \multicolumn{4}{|c|}{ Level of Influence } & \multicolumn{3}{|l|}{ Intent } & \multirow{2}{*}{$\begin{array}{l}\text { Implementation vs } \\
\text { Dissemination } \\
\text { I= Implementation } \\
D=\text { Dissemination }\end{array}$} & \multirow{2}{*}{$\begin{array}{l}\text { Target Group } \\
\mathrm{PT}=\text { Patient } \\
\mathrm{PR}=\text { Provider } \\
\mathrm{PM}=\text { Policy makers }\end{array}$} \\
\hline & & Individual & Organization & Community & System & Policy & Education & Practice & & \\
\hline \multicolumn{11}{|l|}{ Behaviour Change } \\
\hline Abraham 2008 [22] & B & $\cdot$ & & & & & & $\cdot$ & I & PT \\
\hline Albrecht 2013 [23] & B & $\cdot$ & $\cdot$ & $\cdot$ & $\cdot$ & & $\cdot$ & $\cdot$ & I \&D & $P R$ \\
\hline Czaja 2003 [29] & $B \& S$ & . & . & . & . & & . & - & । & PT \& PR \\
\hline Dixon 2010 [31] & B & $\cdot$ & $\cdot$ & & & $\cdot$ & $\cdot$ & $\cdot$ & I \&D & PT \& PR \\
\hline Lowe 2011 [43] & B & $\cdot$ & & & $\cdot$ & • & $\cdot$ & $\cdot$ & । & PT \\
\hline Michie 2011a [45] & $B \& S$ & $\cdot$ & $\cdot$ & & $\cdot$ & $\cdot$ & & $\cdot$ & 1 & PT \& PR \\
\hline Michie 2011b [46] & s & $\cdot$ & $\cdot$ & & $\cdot$ & & & $\cdot$ & । & PT \& PR \\
\hline Michie 2011c [47] & s & . & . & & · & - & & . & । & PT \& PR \\
\hline Michie 2012 [48] & $B \& S$ & $\cdot$ & $\cdot$ & & $\cdot$ & $\cdot$ & & $\cdot$ & । & $P R$ \\
\hline Walter 2003 [55] & B & $\cdot$ & $\cdot$ & $\cdot$ & $\cdot$ & $\cdot$ & & $\cdot$ & $I \& D$ & $P R$ \\
\hline \multicolumn{11}{|l|}{ Population Health } \\
\hline CIHI 2001 [28] & B & & . & . & . & . & & & $\mathrm{D}$ & $P R$ \\
\hline Hendriks 2013 [38] & B & & & & $\cdot$ & $\cdot$ & & & I & PM \\
\hline Keller 2004 [39] & B & $\cdot$ & & $\cdot$ & $\cdot$ & & & $\cdot$ & । & $P R$ \\
\hline Lamb 2011 [40] & S & & $\cdot$ & & & & & $\cdot$ & 1 & $P R$ \\
\hline Lavis 2006 [41] & B & & & & $\cdot$ & $\cdot$ & & $\cdot$ & $1 \& D$ & $P R$ \\
\hline Nuffield 2007 [49] & B & & & & $\cdot$ & · & & & । & $P R$ \\
\hline \multicolumn{11}{|l|}{ General } \\
\hline Best 2008 [24] & $B \& S$ & $\cdot$ & $\cdot$ & $\cdot$ & $\cdot$ & $\cdot$ & $\cdot$ & $\cdot$ & I \& D & PT \& PR \\
\hline Cane 2012 [25] & B & $\cdot$ & & & & & & $\cdot$ & । & $P R$ \\
\hline Carlson 2010 [26] & B & & $\cdot$ & & $\cdot$ & · & & & । & $P R$ \\
\hline Century 2012 [27] & B & & $\cdot$ & & $\cdot$ & & $\cdot$ & & 1 & $P R$ \\
\hline $\begin{array}{l}\text { Damschroder } 2009 \\
\text { [30] }\end{array}$ & B & & . & . & . & . & · & · & । & $P R$ \\
\hline Dogherty 2010 [32] & B & - & $\cdot$ & & & & & $\cdot$ & । & $P R$ \\
\hline Dy 2011 [33] & S & & $\cdot$ & $\cdot$ & $\cdot$ & $\cdot$ & $\cdot$ & $\cdot$ & I & PR \\
\hline EPOC 2010 [34] & B & $\cdot$ & $\cdot$ & $\cdot$ & $\cdot$ & $\cdot$ & $\cdot$ & $\cdot$ & I \&D & PT \& PR \\
\hline Galbraith 2011 [35] & B & $\cdot$ & & $\cdot$ & & & . & $\cdot$ & । & $P R$ \\
\hline Gifford 2013 [36] & S & $\cdot$ & $\cdot$ & & & & & $\cdot$ & I & $P R$ \\
\hline Greenhalgh 2004 [37] & B & . & . & . & . & . & . & $\cdot$ & $I \& D$ & $P R$ \\
\hline Leeman 2007 [42] & B & $\cdot$ & $\cdot$ & & & & & $\cdot$ & । & $P R$ \\
\hline Mazza 2013 [44] & B & & & & $\cdot$ & $\cdot$ & & & । & $P R$ \\
\hline Powell 2012 [50] & B & & $\cdot$ & & · & & & $\cdot$ & 1 & $P R$ \\
\hline Schulz 2010 [51] & s & $\cdot$ & $\cdot$ & & & & & $\cdot$ & । & $P R$ \\
\hline Shojania 2004 [52] & B & $\cdot$ & $\cdot$ & $\cdot$ & $\cdot$ & $\cdot$ & $\cdot$ & $\cdot$ & $1 \& D$ & PT \& PR \\
\hline Stirman 2013 [53] & B & $\cdot$ & · & $\cdot$ & & $\cdot$ & $\cdot$ & $\cdot$ & । & $P R$ \\
\hline Taylor 2011 [54] & B & $\cdot$ & · & & & & & · & । & PT \& PR \\
\hline Ward 2010 [56] & B & & - & - & - & $\cdot$ & & . & I & PR \\
\hline
\end{tabular}

Implementation and dissemination attributes of schemes The focus of the schemes was predominantly implementation activities focused on the process of using evidence within the given setting $(n=26)[22,25-27,29,30,32$,
33, 35, 36, 38-40, 42-51, 53, 54, 56]. Eight schemes focused on both implementation and dissemination activities [23, 24, 31, 34, 37, 41, 52, 55], and one scheme focused on dissemination only [28]. 


\section{Target group}

The most frequent group targeted by the classification scheme was healthcare or service providers $(n=23)$ [23, 25-28, 30, 32, 33, 35-37, 39-42, 44, 48-51, 53, 55, 56]. Nine schemes targeted both patients/clients and providers $[24,29,31,34,45-47,52,54]$, two schemes targeted patients/clients alone [22, 43], and one scheme targeted policy makers [38].

\section{Discussion}

This in-depth review delivers key information on a diverse set of classification schemes of interventions for implementing evidence into healthcare, providing a needed resource for researchers to select a classification scheme most appropriate for their purpose and setting. With a dearth of evidence to guide the selection of the most appropriate framework(s) for specific contexts and purposes [57], this study builds on previous work, and broadly categorizes the classification schemes as recommended or not recommended. The results of this project have confirmed the availability of diverse classification schemes for interventions to implement evidence into healthcare, but with variable quality. Notably, there was substantial growth in the publication of classification schemes beginning in 2010. Twenty-three of the classification schemes included in this project were published between 2010 and 2013, compared to 12 published in the preceding nine years. This growth coincides with the advancement of the field, which began in earnest in the mid-1990s and has rapidly expanded $[58,59]$. Scientific advancement has led to a dramatic increase in published research and initiated calls for improved methodological rigour within implementation science [60-64]. This, in turn, has led to the publication of frameworks and tools to support the development, implementation, evaluation, and reporting of $\mathrm{KT}$ research [1, 2, 65]. However, up until now, there has not been a consistent method developed to assess the quality or methodological rigour of these frameworks and tools. We found that the rigour of development varied among the schemes, with many low scores, which further supports the need to increase the rigour, transparency and credibility of these classification schemes as well as other frameworks and tools. Overall, 'recommended' classification schemes demonstrated higher quality scores. Recommended classification schemes had significantly more recent publication dates compared to schemes that were not recommended. They also had more citations per year since publication than did the classifications schemes not recommended. These findings are likely due to the advancements made in the rigour of $\mathrm{KT}$ as a science in recent years.

Of the recommended classification schemes, a factor of particular interest was adaptability. Specific classification schemes have been tested in or applied to specific situations, and can offer a 'grab-and-go' solution, provided the purpose of the scheme aligns with researchers' goals and context. For example, Michie and colleagues specifically developed classification schemes (also referred to as taxonomies) for physical activity, healthy eating behaviours [46] and smoking cessation [47]. In contrast, the initial taxonomy/list of behaviour change techniques developed by Abraham and Michie [22] was intended to be more broadly applicable. In this manner, the broad adaptability definition enables greater flexibility to adapt the classification scheme to specific activities and/or contexts, which is especially important if no relevant specific scheme exists. In fact, the majority of the highly cited (i.e., more than 100 citations) 'recommended' classification schemes demonstrated broad adaptability $(n=8 / 10)$; however, questions remain about how to best select from and adapt similar broad classification schemes. For those classification schemes that were labeled both broad and specific, some were first identified as being broadly applicable but were also specifically tested in a given area, which provides a starting point for those researchers who might be working in that area $[45,48]$. Others were originally identified as being developed for a specific context or using a specific population, but are described as having broader applicability in other clinical areas [24, 29].

Many of these classification schemes are linked, either by the authors working together or by extending existing schemes [1]. For example, three of the papers by Michie et al. started with the behaviour change techniques (BCTs) identified in the Abraham and Michie paper [22] and produced a more specific/tailored scheme for a particular clinical context (e.g., smoking cessation) [46-48]. Mazza et al. [44] and Shojania et al. [52] each started with, and built upon, the Effective Practice and Organization of Care (EPOC) taxonomy, but unlike the papers by Michie et al., they did not result in a more specific scheme; they are both still categorized as having broad adaptability. Powell et al. [50] built upon Damschroder's Consolidated Framework for Implementation Research (CFIR) [30], and these authors together (with others) expanded it yet again in 2015 [66]. Schulz et al. [51] built upon the work done by Czaja et al. [29] (both authors are on both papers). If a researcher is interested in adapting or extending a current scheme, it would be worthwhile to see what has already been done or start with one of the current broad schemes that others have found to be a valuable starting point (e.g., EPOC and the BCTs).

Other key factors to guide selection of best classification schemes include field of application, areas in which the tool has been tested, whether it is specific to implementation or dissemination, target group, socioecologic level, and intent (i.e., policy, education, practice). Future research should describe the selection and evaluation of 
specific KT intervention classification schemes to illuminate the decision-making process, pros and cons of the classification scheme in practice, and any necessary adaptations required to use the tool in a specific context. This would help contextualize the assessment and categorizations presented here and clarify whether these variables are important for researchers when making these decisions.

Nine classification schemes were 'not recommended', scoring $\leq 4$ out of 7 . These low scores reflected lack of rigour in tool development, limited applicability, and issues related to lack of stakeholder involvement and editorial independence. Eight of nine classification schemes designated 'not recommended' were published before the year 2010 and before the rapid accumulation of KT guidance with improved methodological rigour caused older constructs to become outdated. At present, three of the 'not recommended' classification schemes are highly cited (i.e., more than 100 citations) [14, 17, 18], leading to questions of de-adoption. De-adoption refers to the process of discontinuing a health practice, service, intervention that has been shown to be ineffective [67]. Future research should ascertain whether these classification schemes are of low value in all fields, explore mechanisms to reduce use, and evaluate effectiveness and sustainability of de-adoption strategies [68].

Using the same cohort of classification schemes for KT interventions, an international team recently created a new overarching KT schema (Aims, Ingredients, Mechanism, Delivery [AIMD] framework) $[57,69]$. The AIMD framework is specific to the development and reporting of KT interventions and proposed as an easy-to-use tool to reduce the 'noise' from the litany of available classification schemes and standardize terminology. Preliminary pilot testing and validation work have demonstrated promising results [57]; however, AIMD has yet to be experimentally evaluated and it does not incorporate additional, key implementation factors, such as context. Future research evaluating the AIMD framework and comparing it to existing classification schemes would help elucidate the path forward for KT science.

\section{Strengths and limitations}

This study has several strengths. First and foremost, this is a user driven study. A group of multidisciplinary researchers and knowledge users converged to become a team focused on offering practical guidance to select a classification scheme for implementation of evidence into healthcare. Together we identified a need for further research to provide more detailed information necessary to guide the practical work of KT researchers. The application of a quality appraisal tool, to ascertain the methodological rigour of these schemes, has not been conducted previously and provides a novel and meaningful method for categorizing and assessing them.

This study also has limitations. The literature was not systematically searched for an updated, expanded set of classification schemes; instead, we assessed the classification schemes identified by Lokker and colleagues [1]. Critical appraisal of the quality of classification schemes was assessed using an adapted version of the AGREE II tool; while the adapted tool has face and content validity it has not yet been tested for reliability or construct validity. To our knowledge, our adaptation of the AGREE II tool is the only resource available for critical appraisal of KT intervention classification schemes. Future research could assess the adapted tool's psychometric properties.

\section{Conclusion}

This study reviewed the previously published classification schemes of KT interventions to promote and integrate evidence into healthcare practice, and provided a quality appraisal of these schemes. We extracted additional information from included articles of a scoping review, assessed the developmental and methodological quality of each and made recommendations. Our examination identified 35 classification schemes that may be applicable for researchers and other stakeholders interested in KT in healthcare. We anticipate that our additional categorization and quality appraisal will serve as a practical resource for researchers by facilitating the selection of suitable classification schemes for the researchers' context and purpose.

\section{Additional file}

Additional file 1: Adaptations of the AGREE II tool. (DOCX $21 \mathrm{~kb}$ )

\section{Abbreviations}

AIMD: Aims, Ingredients, Mechanism, Delivery; BCTs: Behaviour change techniques; CFIR: Consolidated Framework for Implementation Research; EPOC: Effective Practice and Organization of Care; KT: Knowledge translation; SPOR: Strategy for Patient Oriented Research

\section{Acknowledgements \\ Not applicable. \\ Funding \\ This work was supported by the Alberta SPOR SUPPORT Unit KT Platform.}

Availability of data and materials

All data generated or analysed during the current study are available from the corresponding author on reasonable request.

\section{Authors' contributions}

All authors participated in conception and design, data abstraction and interpretation, and drafting and critically revising the manuscript. All authors have read the final draft and have approved this manuscript.

Ethics approval and consent to participate

This study did not involve human participants, data or tissue. Neither did it involve animals. 


\section{Consent for publication}

Not applicable.

\section{Competing interests}

The authors declare that they have no competing interests.

\section{Publisher's Note}

Springer Nature remains neutral with regard to jurisdictional claims in published maps and institutional affiliations.

\section{Author details}

${ }^{1}$ University of Alberta, Edmonton, Canada. ${ }^{2}$ Alberta SPOR SUPPORT Unit KT Platform, Edmonton, Canada. ${ }^{3}$ University of Calgary, Calgary, Canada. ${ }^{4}$ Alberta Health Services, Calgary, Canada.

Received: 31 August 2017 Accepted: 22 November 2017

Published online: 06 December 2017

\section{References}

1. Lokker C, McKibbon KA, Colquhoun H, Hempel S. A scoping review of classification schemes of interventions to promote and integrate evidence into practice in healthcare. Implement Sci. 2015:10:27.

2. Tabak R, Khoong E, Chambers D, Brownson R. Bridging research and practice: models for dissemination and implementation research. Am J Prev Med. 2012;43(3):337-50.

3. The Center for Research in Implementation Science and Prevention. Dissemination \& Implementation Models in Health Research \& Practice. http://dissemination-implementation.com/index.aspx (2017). Accessed 8 March 2017.

4. Milat A, Li B. Narrative review of frameworks for translating research evidence into policy and practice. Public Health Res Pract. 2017;27(1):1-13.

5. Brouwers M, Kho M, Browman G, Cluzeau F, Feder G, Fervers B, et al. AGREE II: advancing guideline development, reporting and evaluation in healthcare. Can Med Assoc J. 2010;182:E839-42.

6. Agency for Healthcare Research and Quality. Patient Safety Network Approach to improving safety. 2013.

7. Abraham C, Kok G, Schaalma H, Luszczynska A. Health promotion. In: Martin P, Cheung F, Knowles M, Kyrios M, Overmier J, Prieto J, editors. The International Association of Applied Psychology: handbook of applied psychology. Oxford: Wiley-Blackwell; 2011.

8. Bartholomew L, Parcel G, Kok G, Gottlieb N. Planning health promotion programs: intervention mapping. San Francisco: Jossey-Bass; 2011

9. McMaster Health Forum. Health Systems Evidence. http://www. healthsystemsevidence.org/open-search.aspx (2013). Accessed 4 May 2016

10. Evenboer K, Huyghen A, Tuinstra J, Knorth E, Reijneveld S. A taxonomy of care for youth: results of an empirical development procedure. Res Soc Work Pract. 2012;22:637-46.

11. Proctor E, Powell B, McMillen C. Implementation strategies: recommendations for specifying and reporting. Implement Sci. 2013:8:139.

12. Michie S, Johnston M, Francis J, Hardeman W, Eccles M. From theory to intervention: mapping theoretically derived behavioural determinants to behaviour change techniques. Appl Psychol. 2008:57:660-80.

13. Cohen D, Scribner R. An STD/HIV prevention intervention framework. AIDS Patient Care STDs. 2000;14:37-45.

14. Dolan P, Hallsworth M, Halpern D, King D, Vlaev I. MINDSPACE. London: Institute for Government, the Cabinet Office; 2010.

15. Embry D, Biglan A. Evidence-based kernels: fundamental units of behavioral influence. Clin Child Fam Psychol Rev. 2008;11:75-113.

16. Geller E, Berry T, Ludwig T, Evans R, Gilmore M, Clark S. A conceptual framework for developing and evaluating behavior change interventions for injury control. Health Educ Res. 1990;5:125-37.

17. Goel P, Ross-Degnan D, Berman P, Soumerai S. Retail pharmacies in developing countries: a behavior and intervention framework. Soc Sci Med. 1996:42:1155-61.

18. Hardeman W, Griffin S, Johnston M, Kinmonth A, Wareham N. Interventions to prevent weight gain: a systematic review of psychological models and behaviour change methods. Int J Obes Relat Metab Disord. 2000;24:131-43.

19. Perdue W, Mensah G, Goodman R, Moulton A. A legal framework for preventing cardiovascular diseases. Am J Prev Med. 2005;29:139-45.

20. Reisman A. Transfer of technologies: a cross-disciplinary taxonomy. Omega. 2005:33:189-202.
21. West R. Tobacco control: present and future. Br Med Bull. 2006;77-78:123-36.

22. Abraham C, Michie S. A taxonomy of behavior change techniques used in interventions. Health Psychol. 2008;27:379-87.

23. Albrecht $L$, Archibald M, Arseneau D, Scott S. Development of a checklist to assess the quality of reporting of knowledge translation interventions using the workgroup for intervention development and evaluation research (WIDER) recommendations. Implement Sci. 2013;8:52.

24. Best A, R Hiatt R, Norman C. Knowledge integration: conceptualizing communications in cancer control systems. Patient Educ Couns. 2008;71: 319-27.

25. Cane J, O'Connor D, Michie S. Validation of the theoretical domains framework for use in behaviour change and implementation research. Implement Sci. 2012;7:37.

26. Carlson J, Sullivan S, Garrison L, Neumann P, Veenstra D. Linking payment to health outcomes: a taxonomy and examination of performance-based reimbursement schemes between healthcare payers and manufacturers. Health Policy. 2010;96:179-90.

27. Century J, Cassata A, Rudnick M, Freeman C. Measuring enactment of innovations and the factors that affect implementation and sustainability: moving toward common language and shared conceptual understanding. J Behav Health Serv Res. 2012:14:37-45.

28. Canadian Population Health Initiative. An environmental scan of research transfer strategies. Ottawa: Canadian Institute for Health Information; 2001.

29. Czaja S, Schulz R, Lee C, Belle S. A methodology for describing and decomposing complex psychosocial and behavioral interventions. Psychol Aging. 2003;18:385-95

30. Damschroder L, Aron D, Keith R, Kirsh S, Alexander J, Lowery J. Fostering implementation of health services research findings into practice: a consolidated framework for advancing implementation science. Implement Sci. 2009;4:50

31. Dixon D, Johnston M. Health behaviour change competency framework: competences to deliver interventions to change lifestyle behaviours that affect health. NHS Health: Scotland; 2010.

32. Dogherty E, Harrison M, Graham I. Facilitation as a role and process in achieving evidence-based practice in nursing: a focused review of concept and meaning. Worldviews Evid-Based Nurs. 2010;7:76-113.

33. Dy S, Taylor S, Carr L, Foy R, Pronovost P, Ovretveit J, et al. A framework for classifying patient safety practices: results from an expert consensus process BMJ Qual Saf. 2011;20:618-24.

34. Cochrane Effective Practice and Organisation of Care Group: EPOC resources of review authors. http://epoc.cochrane.org/epoc-taxonomy (2012). Accessed 4 May 2016.

35. Galbraith J, Herbst J, Whittier D, Jones P, Smith B, Uhl G, et al. Taxonomy for strengthening the identification of core elements for evidence-based behavioral interventions for HIV/AIDS prevention. Health Educ Res. 2011;26: 872-85.

36. Gifford W, Davies B, Graham I, Tourangeau A, Woodend A, Lefebre N. Developing leadership capacity for guideline use: a pilot cluster randomized control trial. Worldviews Evid-Based Nurs. 2013:10:51-65.

37. Greenhalgh T, Robert G, Macfarlane F, Bate P, Kyriakidou O. Diffusion of innovations in service organizations: systematic review and recommendations. Milbank Q. 2004;82(4):581-629.

38. Hendriks A, Jansen M, Gubbels J, De Vries N, Paulussen T, Kremers S. Proposing a conceptual framework for integrated local public health policy, applied to childhood obesity — the behavior change ball. Implement Sci. 2013;8:46.

39. Keller L, Strohschein S, Lia-Hoagberg B, Schaffer M. Population-based public health interventions: practice-based and evidence-supported. Part 1. Public Health Nurs. 2004:21:453-68.

40. Lamb S, Becker C, Gillespie L, Smith J, Finnegan S, Potter R, et al. Reporting of complex interventions in clinical trials: development of a taxonomy to classify and describe fall-prevention interventions. Trials. 2011;12:125.

41. Lavis J, Lomas J, Hamid M, Sewankambo N. Assessing country level efforts to link research to action. Bull WHO. 2006:84(8):620-8.

42. Leeman J, Baernholdt M, Sandelowski M. Developing a theory-based taxonomy of methods for implementing change in practice. J Adv Nurs. 2007:58:191-200.

43. Lowe D, Ryan R, Santesso N, Hill S. Development of a taxonomy of interventions to organise the evidence on consumers' medicines use. Patient Educ Couns. 2011:85:e101-7. 
44. Mazza D, Bairstow P, Buchan H, Chakraborty S, VanHecke O, Grech C, et al. Refining a taxonomy for guideline implementation: results of an exercise in abstract classification. Implement Sci. 2013;8:32.

45. Michie S, van Stralen M, West R. The behaviour change wheel: a new method for characterising and designing behaviour change interventions. Implement Sci. 2011;6:42.

46. Michie S, Ashford S, Sniehotta F, Dombrowski S, Bishop A, French D. A refined taxonomy of behaviour change techniques to help people change their physical activity and healthy eating behaviours: the CALO-RE taxonomy. Psychol Health. 2011;26p:1479-98.

47. Michie S, Hyder N, Walia A, West R. Development of a taxonomy of behaviour change techniques used in individual behavioural support for smoking cessation. Addict Behav. 2011;36:315-9.

48. Michie S, Whittington C, Hamoudi Z, Zarnani F, Tober G, West R. Identification of behaviour change techniques to reduce excessive alcohol consumption. Addiction. 2012;107:1431-40.

49. Nuffield Council on Bioethics. Public health: ethical issues: a guide to the report. London: Nuffield Council on Bioethics; 2007.

50. Powell B, McMillen J, Proctor E, Carpenter C, Griffey R, Bunger A, et al. A compilation of strategies for implementing clinical innovations in health and mental health. Med Care Res Rev. 2012;69:123-57.

51. Schulz R, Czaja S, McKay J, Ory M, Belle S. Intervention taxonomy (ITAX): describing essential features of interventions. Am J Health Behav. 2010;12: 811-21.

52. Shojania KG, McDonald KM, Wachter RM, Owens DK. Closing the quality gap: a critical analysis of quality improvement strategies, volume 1-series overview and methodology. Technical review 9 (contract no. 290-02-0017 to the Stanford University-UCSF evidence-based practices center). AHRQ publication no. 04-0051-1. Rockville: Agency for Healthcare Research and Quality. 2004

53. Stirman S, Miller C, Toder K, Calloway A. Development of a framework and coding system for modifications and adaptations of evidence-based interventions. Implement Sci. 2013;8:65.

54. Taylor S, Dy S, Foy R, Hempel S, McDonald K, Ovretveit J, et al. What context features might be important determinants of the effectiveness of patient safety practice interventions? BMJ Qual Saf. 2011;20:611-7.

55. Walter I, Nutley S, Davies H. Developing a taxonomy of interventions used to increase the impact of research. St. Andrews, Scotland: University of St. Andrews; 2003.

56. Ward V, Smith S, Carruthers S, House A, Hamer S. Knowledge brokering Exploring the process of transferring knowledge into action. Leeds: University of Leeds; 2010.

57. Bragge $P$, Grimshaw J, Lokker C, Colquhoun H, The AIMD Writing/Working Group. AIMD - a validated, simplified framework of interventions to promote and integrate evidence into health practices, systems, and policies. BMC Med Res Methodol. 2017;17:38.

58. Estabrooks C, Derksen L, Winther C, Lavis J, Scott S, Wallin L, ProfettoMcGrath J. The intellectual structure and substance of the knowledge utilization field: a longitudinal author co-citation analysis, 1945 to 2004. Implement Sci. 2008:3:49.

59. Grimshaw J, Eccles M, Lavis J, Hill S, Squires J. Knowledge translation of research findings. Implement Sci. 2012;7:50.

60. Grimshaw J, Eccles M, Tetroe J. Implementing clinical guidelines: current evidence and future implications. J Contin Educ Heal Prof. 2004;24(S1):S31-7.

61. Walshe K. Pseudoinnovation: the development and spread of healthcare quality improvment methodologies. Int J Qual Health Care. 2009;21(3): 153-9.

62. Michie S, Fixsen D, Grimshaw J. Specifying and reporting complex behaviour change interventions: the need for a scientific method. Implement Sci. 2009;4:40.

63. Bhattacharyya O, Estey E, Zwarenstein M. Methodologies to evaluate the effectiveness of knowledge translation interventions: a primer for researchers and health care managers. J Clin Epidemiol. 2011;64:32-40.

64. Brehaut J, Eva K. Building theories of knowledge translation interventions: use the entire menu of constructs. Implement Sci. 2012;7:114.

65. Davis $D$. The case for knowledge translation: shortening the journey from evidence to effect. BMJ. 2003;327:33.

66. Powell B, Waltz TJ, Chinman MJ, Damschroder LJ, Smith JL, Matthieu MM, et al. A refined compilation of implementation strategies: results from the expert recommendations for Implementating change (ERIC) project. Implement Sci. 2015;10(1):21.
67. Rogers E. The innovation-decision process. In: Diffusion of innovations. New York: Free Press; 2003. p. 168-218.

68. Niven D, Parsons Leigh J, Stelfox H. Ethical considerations in the deadoption of ineffective or harmful aspects of healthcare. Healthc Manage Forum. 2016;29(5):214-7.

69. Colquhoun H, Leeman J, Michie S, Lokker C, Bragge P, Hempel S, et al. Towards a common terminology: a simplified framework of interventions to promote and integrate evidence into health practices, systems and policies. Implement Sci. 2014;9:51.

\section{Submit your next manuscript to BioMed Central and we will help you at every step:}

- We accept pre-submission inquiries

- Our selector tool helps you to find the most relevant journal

- We provide round the clock customer support

- Convenient online submission

- Thorough peer review

- Inclusion in PubMed and all major indexing services

- Maximum visibility for your research

Submit your manuscript at www.biomedcentral.com/submit
) Biomed Central 